\title{
'One day I will pick up a snake, wanting to read it': Becoming a successful reader in a rural environment
}

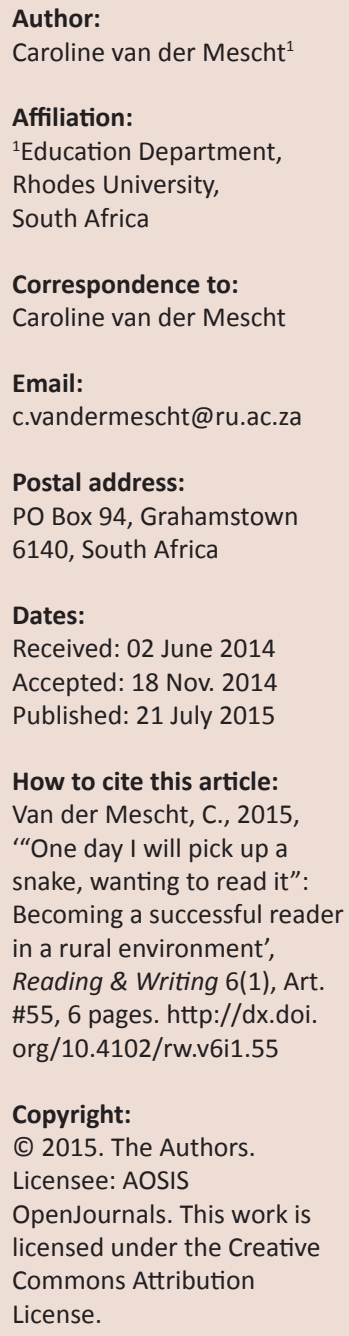

Children learning to read and write in rural areas in Southern Africa perform poorly compared to children in urban schools. The poor results of rural schools in national assessments of reading literacy are explained by the deficits of rural areas: poverty, under-resourced schools and under-qualified teachers. Children in rural areas are frequently not exposed to home literacy practices, which prepare them for formal literacy learning at school. Whilst acknowledging the impact of rural poverty on children's performance, this article explores a role-playing game amongst pre-school and school-going children of rural villages that enabled some children to become successful learners. Focusing on affect, I analyse the way in which the game motivated these children and suggest some of the benefits that promoting this practice may have for teaching and learning in rural areas. The continued underperformance of children in rural schools makes a compelling case for investigating ways of promoting learning and reading in rural homes.

\section{Introduction}

Zhang (2006:583), reviewing the Southern and Eastern African Consortium for Monitoring Education Quality (SACMEQ) findings for 2000, shows that rural children lag behind their counterparts in cities. This is confirmed by other large scale studies, for example, the Progress in International Reading Literacy Study (PIRLS) reports that 'Almost half of the Grade 4 learners came from schools in remote rural areas and achieved more than 100 points less than their urban peers' (Howie, Van Staden, Tshele, Dowse \& Zimmerman 2012:xvii). One hundred points is equivalent to two to three years' of schooling (Howie et al. 2012:xvii). Zhang (2006:592) also highlights the fact that South Africa shows the greatest regional difference in the ability of rural compared to urban primary school readers. Zhang relates these differences to the high unemployment in South African rural areas, where large numbers subsist on grants or remittances. Statistics South Africa (2014:33) reports that $68.8 \%$ of South Africans who live in poverty are in rural areas.

Whilst large-scale studies show inequality in the teaching between urban and rural schools, balancing those inequalities has focused on provisioning schools and training teachers. Little is known of the literacy practices in rural homes that teachers can affirm and build on, although research into family literacy practices has offered intriguing insights (Dixon \& Lewis 2008; Land 2008; Mweru 2011; Prinsloo \& Breier 1996).

This article examines the experiences of teachers who learned to read in disadvantaged rural areas and who went on to become successful students and committed readers. I will first give an overview of how they learned to read, then focus on a key practice referred to by the participants as the 'School Game,' the term I use in this article. After presenting themes drawn from their accounts I will suggest that this game aligns with sound learning practices. The research also provides insight into what motivated these children to persist in reading.

\section{Learning to read in rural South Africa}

In her review of SACMEQ 2000, Zhang (2006:299) summarises the situation by writing that 'rural students, as described above, suffered from inferior home and school circumstances'. Fleisch (2008) gives more detail of an interlocking web of disadvantage, which reaches from the home to the school for underprivileged rural children. At a basic level, the attendance of children from poorly resourced homes is likely to be more intermittent than that of their peers and they are more likely to repeat grades as their families struggle to meet the costs of schooling. In addition, living in poverty affects the health of children and their ability to concentrate when they are at school. They are vulnerable to childhood ailments associated with poverty, for example, asthma, and to undiagnosed parasite infections such as malaria and bilharzia. Rural schools may be too far from the home even for healthy children to walk the distance until they are older. 
There is a general understanding that schools in such circumstances need to make up for the deficits of the home. At the same time, little is known of the literacy practices in rural homes that teachers build on in early literacy learning. Factors in rural homes that make literacy learning difficult for children living in them are the lack of reading materials in households and the low education attainment of rural adults. The PIRLS study (Howie et al. 2012) shows that fewer than $50 \%$ of South African children have more than 10 books in their homes. This can be attributed to poverty, but is also because the highest rate of illiteracy is in rural areas. Disadvantaged rural caregivers are, therefore, unlikely to purchase books or magazines. In addition, studies suggest that parents' education, for many reasons, is a high predictor of children's success at school (Dubow, Boxer \& Huesmann 2009:225).

Research conducted by Land (2008) suggests that for many rural children home based literacy learning imitates caregivers' own school experience of formal drill and repetition. Parents offer their children instruction, based on 'the oldest, most traditional teaching methods. She started off the session by randomly writing letters, moved to vowels and the ... ma, me, mi, and so on' (Land 2008:59). These experiences undoubtedly communicate the importance of literacy and school learning to the child. However, literature on early home literacy suggests that children benefit from interactions that are warm, affirming, playful and fun. This study suggests that children seek out enjoyable literacy learning experiences with other children rather than with parents and adults. This is what helped them become successful readers in disadvantaged rural homes.

\section{Challenging deficit thinking}

Large-scale studies give one picture; individual stories may reveal another. There are indications that disadvantaged children in rural environments do have opportunities to learn to read at home. Firstly, the concept of 'illiterate' parents is a contested one, as is the assumption that rural parents do not value literacy and are not able to help their children. Adults who have low school attainment may still regularly read and write in the home, modelling literacy as a desirable practice. For example, one participant learned to read by sitting on her uncle's lap whilst he did the accounts of his rural store. Another was taught to read by her grandmother, who, as she was going to sleep, traced letters and words on the wall with her finger. The warmth suggested by these accounts is compelling. Significantly, the children who experienced them went on to become successful students, in spite of parents who did not have a high level of school based learning.

Many participants of my study also write of deliberate teaching at home, as Land (2008) describes. They repeated lessons to mothers and were tutored by older cousins, with an emphasis on learning the alphabet, writing one's name and counting. They sat with school-going siblings doing homework, read their books and wrote in the backs of their exercise books. This shows how disadvantaged families use overlapping human and material resources to make up for the deficits in literacy skills or reading materials. By arranging these opportunities for their younger children to learn, adults mark it as a desirable occupation.

These observations align with research described by Fleisch (2008), who asserts that parents with low levels of school attainment may still be ambitious for their children. He writes of 'the extraordinary sacrifices that families make to get and keep their children in school', which shows:

the extent to which families see education, particularly the acquisition of a post-secondary education, as an investment, possibly the most important investment poor people can make in a better future. (Fleisch 2008:77)

An example is of a participant whose mother tore open sugar packets for paper and wrote on them with sticks of charcoal so that her daughter would be ready for school. Rural families may send children to live with relatives in a fostering system that gives the children access to better schools, as was the case with participants in my study.

\section{The value of games and play in learning}

Research into early childhood development affirms the importance of fun and enjoyment in early literacy learning, as well as the benefits of learning through play (Bodrova \& Leong 2005). This research is critical of the formality of the early literacy learning described by Land (2008). Heroman and Copple (2006:68) describe play as a 'nonlinear, dynamic, powerful network of relationships to learning'. A pamphlet distributed by the North Carolina Department of Public Instruction suggests that children learn best in child-initiated play, and lists the benefits:

Play helps children increase their memory, critical thinking skills, self-regulation, social skills, oral language skills, literacy skills, mathematical and problem-solving skills, and lays the foundation for all academic learning. (n.d.:2)

These benefits are differently balanced depending on the structure of the particular game, with some games offering, for example, more social interaction and others more critical thinking skills.

The participants in my study had formative early literacy learning experiences in a role-play game. In this kind of game children imitate a familiar context. This allows children to practise memory, language, social and oral skills, to negotiate, solve problems and practice self-regulation. On a different level, role-play allows children to participate actively in the process of learning. As role-play imitates real life situations it allows children to make sense of the world around them and to explore, experiment and investigate the possibilities of a context. This form of play has particular benefits for communication skills and language learning. Best of all for disadvantaged rural children, role-play games need only the resources children themselves provide. It is therefore potentially a powerful resource for teachers in rural areas to harness for literacy learning in the home. 


\section{Research methodology and theoretical framework}

The data of this research were collected from sixty-one teachers registered for an in-service Bachelor in Education (B.Ed.) degree. All participants agreed to have their stories used for research. These teachers, now aged between 45 and 55 years, all had their initial reading experience in poor rural communities in either the Northern Cape or the Eastern Cape. They were asked to give autobiographical details and a description of a significant memory of learning to read, and to relate it to their teaching. I was primarily interested in how these individuals, who all became teachers and students in a degree programme, learned to read in disadvantaged rural communities.

Specific questions for the research were:

- What early reading experiences did these individuals have which may have contributed to their success as learners and readers?

- How did they feel about these early literacy learning experiences?

- To what extent did these early experiences motivate their later learning?

- Are there early literacy learning experiences in rural areas that local teachers might build on?

The parallels in the teachers' experiences prompted me first to examine common themes. As one of the themes was the emotional associations participants had with reading, I also used categories from Appraisal Theory, a recent development in textual analysis developed by Martin and White (Read, Hope \& Carroll 2007). Similar to Discourse Analysis, Appraisal Theory has developed from Systemic Functional Linguistics and focuses on interpersonal meaning in text through the communication of emotion, judgement or appreciation. Emotion and attitude seemed an important dimension to investigate in accounts such as 'It was quite stunning for me and I felt on top of the world' (Northern Cape, Participant 7).

The participants' accounts show that they grew up and were educated in the rural Northern and Eastern Cape, the most rural provinces in South Africa, where their home literacy was in Setswana or Afrikaans or, isiXhosa. They described homes with no, or few, reading materials. They went to under-resourced schools, where they used slates for writing. There were few books in the classrooms and no sets of readers. Books were not sent home. Some schools were 'platooned,' that is, their classrooms used on alternate mornings and afternoons by two schools. They describe teachers who relied on chanting, rote learning and drill from a blackboard.

In spite of these conditions, which match Zhang's (2006:299) description of 'inferior home and school circumstances' cited above, the majority of participants, or $77 \%$, learned to read before attending school. The average age of their first literacy learning experiences in the Northern Cape cohort was 5 years 6 months and in the Eastern Cape 6 years 4 months. Of those who learned to read at home, $18 \%$ had reading modelled for them by adults in their homes, $20 \%$ were deliberately taught by a family member in the style described by Land (2008) above and 13\% had a relative who was a teacher.

Unexpectedly, the largest proportion, nearly a third of the participants $(29 \%)$, identified a role-playing game, which they called the 'School Game', as their primary home literacy learning. Early home literacy learning experiences are usually assumed to come from the modelling, teaching or participation of literate adults. Peer teaching does not appear in the literature on reading as a strong element in pre-school learning, although paired reading is recommended as a strategy to increase young readers' fluency (Department of Basic Education [DBE] 2010). I was therefore drawn to investigate the participants' accounts of the game and the kinds of reading experience it provided for them.

\section{Findings: The School Game}

For the participants in this study, the School Game was played with school-going children from the household, farmstead or village. Older children already at school took the lead, imitating their own teacher and using their home language (Setswana or isiXhosa). They would write words on a zinc fence or water barrel with charcoal or white clay, or use brown wrapping paper as 'books'. A child playing the role of teacher led the others in recitation and chanting. The School Game may be a gendered activity: participants in this research were all women and rural boys may play different games. Friends and colleagues assert that this game is still played by children from all language and socio economic groups. Rural children of the current generation continue to play the School Game. At a university winter school in 2013, forty one matriculants, who were the top achieving English students from rural schools in the area, all responded that they knew or had played the game as children.

Focusing therefore on the School Game, I first searched inductively for themes. These revealed parallel experiences that culminate in the participants describing themselves as enthusiastic readers and successful students. In a second round of analysis I applied categories of the Appraisal Theory taxonomy to investigate what had generated their emotional connection to reading, whether positive or negative. The analysis suggests that the following five features encouraged participants to read.

Firstly, the participants emphasise that a sense of success, or of overcoming challenge, was an important motivating factor for them. This was often expressed through detailed descriptions of their struggle and effort: the lack of reading materials at home, long distances to walk, harsh discipline at school and few resources available. This struggle, however, is presented as a measure of their success. The greater the effort, 
the greater the sense these individuals had of achievement in adversity. For example:

'I thanked God for the lovely school experience I gained from home [i.e.: the School Game], because it saved me a lot of struggles ... I wholeheartedly thanked God for my sister who gave me the basics, and encouraged me to love reading'. (Northern Cape, Participant 8)

Secondly, participants were motivated by pride in their achievement. Many described significant adults' praise as a marker of success: teachers, librarians, principals and inspectors all contributed to these children's image of themselves as good readers. Other participants ascribed their school readiness to the School Game, and wrote of the pride this gave them. For example, a participant whose sister in Grade Two taught her to read at the age of five wrote:

'When I started school I already had a background of books, so I grasped everything easily and became a fast learner. That motivated me to always do my best in reading because it made me feel proud of myself'. (Northern Cape, Participant 22)

A third motivating factor for participants was that, in their communities, reading was an adult pursuit. Imitating adults' reading gave the children a sense of agency and power, especially if it enabled them to enter the adult life of the family by reading to or for family members. For example, one participant wrote:

'This pretend play school made me very proud of myself and led me to like reading books. As the time went by I learnt to use other books as well as reading the bible for my grandmother and I was bragging about that to my friends'. (Eastern Cape, Participant 5)

In a further step, the School Game enabled some children to take on the role of powerful adults and to explore the practices of schools by imitating their teachers. Some participants describe how they developed strong identities as teachers and successful readers. For example, one participant wrote:

'Being able to read made me feel like a teacher. Whenever I used to play school with my friends I was always the teacher. I had one teacher who was really my role model and I loved to imitate her'. (Northern Cape, Participant 11)

Finally, children used the School Game to mediate their relationships with peers, either by initiating or controlling the direction of the game. One participant used the School Game to escape the local bully who was not fond of school and always avoided them when they played the game!

Appraisal Analysis shows that many participants had an intense emotional response to this experience. Many described reading generally as 'exciting,' or 'interesting,' but some added descriptors like 'stunning,' 'a blessing' or 'I felt on top of the world.' Words like 'love' and 'passionate' were commonly applied to reading. Some read obsessively wherever they found texts, as the following participant relates:

'I never passed a written piece of paper on the street without picking it up and reading it. One day after school I picked up a piece of paper only to realize it was soiled. The other children made it a joke (laughing) saying that it served me right because I liked to pick up paper like a mad person and one day I would pick up a snake wanting to read it. Even after that nasty experience I continued reading every piece of reading material I came across'. (Northern Cape, Participant 32)

Unfortunately, many of them had less positive experiences at school and as a result some stopped reading, or read with little pleasure: 'In the formal school I tended to have a negative attitude towards reading as it was enforced in us with lashes of sticks' (Northern Cape, Participant 8). For others, the positive experience of the game was enough to keep their interest in reading alive. The game seemed to give an early sense of agency and success that survived the potentially damaging school experiences for some individuals.

\section{Discussion: Implications for teaching and learning}

What can we say of the School Game as a reading literacy experience? In addition to the general benefits mentioned earlier, such as learning to cooperate and negotiate, general language skills and self-regulation, the School Game provides the following possible benefits for participating children.

Firstly, the School Game provides mother tongue learning. In environments where the language of learning and teaching is not always the home language of the children, older peers translate literacy practices so that the experience is accessible to the whole group. Whilst research shows that children are not necessarily disadvantaged by learning in an additional language, Home Language learning has many benefits for young children (Cummins 1981). This thinking is behind the new Incremental Introduction of African Languages Draft Policy (DBE 2013).

Secondly, although models of reading usually suggest an adult tutor, peer teaching has a number of advantages. At the moment peer teaching exists in the Curriculum and Assessment Policy Statement (CAPS) as 'paired reading' (DBE 2010). CAPS suggests that paired reading 'provides children with reading practice and encourages reading for enjoyment' (DBE 2010:17) and this was certainly the case in the School Game. CAPS also suggests that 'Paired reading can take place at any time, anywhere, as a class reading activity' (DBE 2010:17). The School Game takes this experience a step further as it adds teaching to the reading practice. Peers take the role of a 'knowledgeable other' (Vygotsky) and, because their own level of learning is very close to that of the other children, scaffold learning experiences at a level that other children will be able to understand and access. At the same time, peers present reading as a prized social occupation in a context where adults are not necessarily modelling the value of school based learning in the home. Furthermore, the School Game, because it is based on the practices of local teachers, prepares children for the teaching style in the local school and gives access to the local community of practice. 
Whatever the effectiveness of that teaching may be, there is an advantage to being familiar with expectations in a new environment.

Thirdly, the School Game provides a space in which children can recall and practise formal learning. One participant comments: 'This helped me a lot because in a way I was reinforcing what I was learning at school even though I was not aware [of it]' (Northern Cape, Participant 37). It has particular benefits for memory training. Not only did children memorise their lessons at school and words from books as material for the School Game, but they also played using those cognitive skills 'The main learning experience was through memorizing and word recognition, as words were written on the side of the big water tank, which was used as a chalkboard' (Northern Cape, Participant 8). Memory training is a powerful tool in the service of literacy learning and probably contributed to the participants' early success.

With regard to memory training it is worth mentioning the concerns raised by Taylor about the 'parrot reading' which prevails in many classrooms (Jansen 2013). Although the participants of this research learned to read a generation ago and much has changed in the resourcing of rural schools, teaching styles have a longer lifespan. The National Education Evaluation and Development Unit (NEEDU) Summary Report 2012 (2013) comments:

Too much time was spent on repetitive chorusing and discussing peripheral textual features. In other words, there appeared to be an emphasis on reading as collective decoding rather than on reading for individual understanding. (p. 7)

It is important to remember that independent reading is the ultimate goal of reading instruction.

A caveat therefore arises: a role-playing game will be limited to the models available to the children who play it. When their teacher has a reduced notion of literacy, or uses an ineffective methodology, for example the repetitive chorusing criticized by the NEEDU report, that understanding will be perpetuated by the children in their game. More encouragingly, a rich engagement with text can also find its way into the School Game. One participant and her friends were taught by a young aunt, and gives this account:

'My aunty used to read in additional language and asked us open-ended questions. She used to read the book and summarized it according to our level because at that time she was in secondary school so she was reading her books and made it simple by translating into our home language. Then she did summary and asked some questions. She used to encourage us to tell others about these stories. Sometimes she also encouraged us to dramatize the story'. (Eastern Cape, Participant 21)

This account shows not only that the model provided by the local teacher is crucial to the School Game experience but also that children are able to imitate a variety of effective teaching methods.

\section{Conclusions and recommendations}

It has become commonplace to blame a range of home and environmental deficits for the low levels of literacy achievement amongst rural and disadvantaged children. The difficulties of becoming a reader in rural South Africa today should not be underestimated. However, this study shows that young children in remote, under-resourced areas have access to pleasurable experiences with texts that set them on a lifelong quest for learning. We should avoid deterministic thinking about the effects of poor rural circumstances.

In conclusion there are two points worth highlighting. Firstly, this research shows the importance of peer teaching within a role-playing framework. It suggests that peer teaching is potentially a powerful structure for learning, especially in rural areas where provisioning schools is still delayed by logistical difficulties. This research suggests that teachers and teacher educators should not underestimate the benefits of play structures such as the School Game, already played by rural school children, to promote extramural learning and positive experiences amongst learners. It reminds teachers and teacher educators that disadvantaged environments may still provide rich, affirming literacy learning experiences for children.

Secondly, this research suggests that teachers in rural and urban schools in South Africa should harness the motivating power of early success. All the participants in this study expressed the importance of a sense of achievement to their reading progress. The School Game benefited them because it accelerated their reading when they were at school and this, even more than enjoyment, was the main motivating mechanism of their later success as students. The pride they felt, and the way in which their reading skills empowered them at home and amongst their peers when they played the School Game, gave them strong identities as readers. To conclude in the words of a participant:

'To add on, it does not mean that the home environment needs to be wealthy or to be in a big city. Rural children can be equally advantaged or even more so, as long as there are adults around to help them learn ... and that is exactly what my mother, my sister, adults who were around me and the children in the village did for me'. (Northern Cape, Participant 7)

\section{Acknowledgements Competing interests}

The author declares that she has had no financial or personal relationship(s) that may have inappropriately influenced her in writing this article.

\section{References}

Bodrova, E. \& Leong, D.J., 2005, 'Uniquely preschool: What research tells us about the ways young children learn', Educational Leadership 63(1), 44-47.

Cummins, J., 1981, 'The role of primary language development in promoting educational success for language minority students,' in California State Department of Education (ed.), Schooling and language minority students: A theoretical framework, California State University, Los Angeles. 
Department of Basic Education, 2010, Curriculum and Assessment Policy Statement English Home Language, Foundation Phase, Government Printer, Pretoria.

Department of Basic Education, 2013, Incremental Introduction of African languages draft policy, Government Printer, Pretoria.

Dixon, K., \& Lewis, K., 2008, 'Parents, teachers and early literacy: The perceptions of parents and teachers of the roles they should play in developing early literacy', in S. Desmond \& M. Elfert (eds.), Family literacy. Experiences from Africa and around the world, UNESCO Institute for Lifelong Learning, Cape Town.

Dubow, E.F., Boxer, P. \& Huesmann, L.R., 2009, 'Long-term effects of parents' education on children's educational and occupational success', Merrill-Palmer Quarterly 55(3), 224-249. http://dx.doi.org/10.1353/mpq.0.0030

Fleisch, B., 2008, Primary education in crisis. Why South African schoolchildren underachieve in reading and mathematics, Juta, Cape Town.

Heroman, C. \& Copple, C., 2006, 'Teaching in the kindergarten year,' in D.F. Gullo (ed.), $K$ today: Teaching and learning in the kindergarten year, pp. 61-68, viewed 12 May 2014, from www.naeyc.org/files/naeyc/file/Play/Ktodayplay.pdf

Howie, S., van Staden S., Tshele, M., Dowse, C., \& Zimmerman, L., 2012, PIRLS 2011: Summary Report, South African Children's reading literacy achievement, University of Pretoria, Centre for Evaluation and Assessment, Pretoria.

Jansen, L., 2013, 'SA's shocking literacy stats', The Mercury, 22 October 2013.

Land, S., 2008, 'Whose family literacy? Is there a 'right' kind of family literacy that is exclusively middle class and Eurocentric?', in S. Desmond \& M. Elfert (eds.) Family literacy. Experiences from Africa and around the world, UNESCO Institute for Lifelong Learning, Cape Town.
Mweru, M., 2011, 'Sibling caregiving and the teaching roles of children during the early years in Kenya,' in A. Bame Nsamenang \& T. Tchombe (eds.), Handbook of African educational theories and practices: A generative teacher education curriculum, Human Development Resource Centre (HDRC), Cameroon.

National Education Evaluation and Development Unit (NEEDU), 2013, National report 2012, Pretoria.

North Carolina Department of Public Instruction n.d., The power of play in kindergarten, State Board of Education, Office of Early Learning (Pre-K - Grade 3), viewed 12 May 2014 from http://www.ncpublicschools.org/earlylearning/

Prinsloo, M. \& Breier, M., 1996, The social uses of literacy: Theory and practice in contemporary South Africa, SACHED Books, Bertham, South Africa. http://dx.doi. org/10.1075/swll.4

Read, J., Hope, D., \& Carroll, J., 2007, 'Annotating Expressions of Appraisal in English', Proceedings of the linguistic annotation workshop, Praque, June 2007, Association for Computational Linguistics, pp. 93-100.

Statistics South Africa, 2014, 'Poverty Trends in South Africa. An examination of absolute poverty between 2006 and 2011, Report No. 03-10-06', Statistics South Africa, Pretoria.

Zhang, Y., 2006, 'Urban-Rural Literacy Gaps in Sub-Saharan Africa: The Roles of Socioeconomic Status and School Quality', Comparative Education Review 50(4), 581-602. http://dx.doi.org/10.1086/507056 